This PDF is a selection from a published volume from the National Bureau of Economic Research

Volume Title: Risk Topography: Systemic Risk and Macro Modeling

Volume Author/Editor: Markus Brunnermeier and Arvind Krishnamurthy, editors

Volume Publisher: University of Chicago Press

Volume ISBN: 0-226-07773-X (cloth); 978-0-226-07773-4 (cloth); 978-0-226-09264-5 (elSBN)

Volume URL: http://www.nber.org/books/brun11-1

Conference Date: April 28, 2011

Publication Date: August 2014

Chapter Title: A Macroeconomist's Wish List of Financial Data Chapter Author(s): V. V. Chari

Chapter URL: http://www.nber.org/chapters/c12555

Chapter pages in book: (p. 215 - 232) 


\title{
A Macroeconomist's Wish List of Financial Data
}

\author{
V. V. Chari
}

\subsection{Introduction}

Developing an understanding of how financial market disturbances affect the broader economy is crucial for designing appropriate regulatory policy on financial markets. In this chapter I argue that both policymaking and research could be advanced with new data.

- What data do we need? We need financial statements of nonpublic firms. Recent research on general equilibrium models with financial frictions offers a great deal of promise in understanding links between financial markets and the rest of the economy. In particular, many recent models focus on how frictions in financial markets impede firms' investment decisions. Further development of this class of models requires data on the financial statements of nonfinancial firms. Such data is available for publicly traded firms but is not available for privately held firms in the United States.

- Where is this data available? Such data is available from the tax returns that corporations file, as well as the statements firms make available to financial intermediaries when they seek to borrow funds, but detailed

V. V. Chari is the Paul W. Frenzel Land Grant Professor of Liberal Arts and professor of economics at the University of Minnesota and an adviser at the Federal Reserve Bank of Minneapolis.

I thank the National Science Foundation for financial support, Alessandro Dovis and Ariel Zetlin-Jones for technical assistance and useful comments, and the participants at the NBER systemic risk conference, especially Markus Brunnermeier, Arvind Krishnamurthy, and Luigi Zingales for useful comments. The views expressed herein are those of the author and not necessarily those of the Federal Reserve Bank of Minneapolis or the Federal Reserve System. For acknowledgments, sources of research support, and disclosure of the author's material financial relationships, if any, please see http://www.nber.org/chapters/c12555.ack. 
data on individual firms is not publicly available. If confidentiality concerns imply that data on individual nonpublic firms cannot be available, selected statistics can help.

- How would this data help? Making this kind of data more publicly available would help academics develop better models and would also help make policy.

The need for this kind of data starts with the recognition that financial crises are a recurrent feature of capitalist economies. Such crises manifest themselves in a variety of ways, including sharp declines in the value of assets traded in financial markets and the threatened or actual failure of financial intermediaries. Some crises are associated with banking panics and often a widening of interest rate spreads between relatively safe assets and relatively risky assets. Typically, financial crises are associated with sharp declines in economic activity. Such declines typically reach well beyond the financial sector and affect firms and households in a variety of industries. (See Reinhart and Rogoff [2009], for a recent study of financial crises in a variety of countries over a number of years, and the associated fluctuations in economic activity.) An understanding of the sources of financial crises and the mechanisms whereby disruptions in financial markets affect economic activity more generally is essential in developing policies and designing institutional arrangements whereby such crises can be avoided and the effects on economic activity mitigated.

Developing this understanding necessarily requires developing models in which financial market disturbances affect broader economic activity. One can imagine a variety of ways in which financial market disturbances affect real economic activity. Here, I focus on models in which financial market disturbances affect economic activity through the investment channel. Specifically, I will focus on models in which shocks affect the ability of firms to finance investment. Fluctuations in the volume of investment in such models affect output and employment. Focusing on such models excludes models in which financial market disturbances affect working capital, for example, though some of the issues that I raise also apply to such models.

An academic literature over the last decade or so has made a promising start at developing models in which financial frictions affect the aggregate economy primarily through their effect on investment decisions (see, for example, Bernanke, Gertler, Gilchrist [1999] and Kiyotaki and Moore [1997]). These models assume that firms are confronted with a variety of frictions arising from financial markets that limit the extent to which they can use external funds to make profitable investments. From a conceptual point of view, it is useful to divide these models into two broad classes. One class of such models uses what I will call the representative firm construct. The other class consists of models in which heterogeneity across firms plays an essential role in the way aggregate investment is affected by financial market 
disturbances and I will refer to this class as using a heterogeneous firm construct. With a representative firm, to a first approximation, all production of nonfinancial goods and services can be usefully thought of as occurring within a typical or representative firm. In particular, reallocation of funds from one set of firms to another set plays no essential role in the way financial frictions affect economic activity. Leading examples of the representative firm construct are Bernanke, Gertler, and Gilchrist (1999), Jermann and Quadrini (2012), and Eisfeldt and Rampini (2009). It is worth emphasizing that in Bernanke, Gertler, and Gilchrist's formulation, all firms are not alike but the economy behaves as if a nonfinancial activity occurs within a representative firm. Leading examples of models that use the heterogeneous firm construct are Kiyotaki and Moore (1997), Eisfeldt and Rampini (2006), and Shourideh and Zetlin-Jones (2012).

I argue that the data strongly suggest that the representative firm construct is not a useful way to proceed if one is interested in developing models in which financial frictions affect economic activity through the investment channel. I go on to argue that the heterogeneous firm construct is more promising. Realizing that promise requires, however, obtaining and using disaggregated data on fund flows between firms and financial intermediaries.

The main problem with the representative firm construct is that in the aggregate, nonfinancial firms generate significantly more cash from their operations than is needed to finance their investments. These excess funds are, of course, returned to shareholders in the form of dividends, stock buybacks, and the like. Using data from the Flow of Funds for the United States, I show that in essentially every quarter over the postwar period, firms in the aggregate generated more cash from their operations than they used for investment. That is, in essentially every quarter over the postwar period, in the aggregate, funds flow from nonfinancial firms to households after investment expenditures have been made. In models with financial frictions, external funds are more expensive than internal funds. This difference in costs creates strong incentives for firms to delay paying dividends rather than using external funds for investment. This delay delivers higher returns to shareholders, and to use those proceeds for investment. The observation that, in the aggregate, firms pay dividends rather than delaying them creates a challenge for representative firm models.

Heterogeneous firm models, however, hold promise. These models emphasize the role of financial markets in reallocating funds from relatively cashrich firms without plentiful projects in which to make investments to cashpoor, project-rich firms. From the perspective of these models, disturbances in financial markets can adversely affect economic activity by reducing resource reallocation from firms with relatively poor investment opportunities to firms with good investment opportunities. Determining how financial market disturbances affect the broader economy requires a measure of the amount of resource reallocation across firms that is conducted through 
financial markets. A key statistic to measure this resource reallocation is what I call an external funding measure. This statistic measures the amount of investment that is financed by financial markets. Shourideh and ZetlinJones (2012) use this measure to discipline their general equilibrium model of financial frictions operating through the investment channel. In this sense this measure has already proven useful in academic work. This measure is also likely to be useful for policymakers. It provides them a real-time statistic that will be useful in determining the way financial market disturbances are affecting the broader economy.

Realizing the promise of heterogeneous firm models ideally requires that we have access to the financial statements of firms. Such data is typically available for firms whose shares are traded in public stock markets (from sources such as COMPUSTAT). Such data is available for European countries for the last decade or so for a broader set of firms, including privately held firms. Shourideh and Zetlin-Jones (2012) show that the amount to which privately held firms use external funding for investment is much greater than for publicly held firms. This finding is promising for heterogeneous firm models but also makes clear the urgent need to have such data for the United States.

These findings lead to a specific set of proposals. The ideal outcome would be to obtain financial statements, including balance sheets, income statements, and flow of funds statements for all nonfinancial corporations in the United States. Such data is available for publicly held firms, but as I have argued, appears to be most important for privately held firms. The Internal Revenue Service already has this data since all corporations, including privately held ones, are required to report extensive information on their finances along with their tax returns. In principle, the IRS could make available a suitably chosen random sample of this data.

If the IRS is unwilling to make this data public, the Federal Reserve or other organizations could conduct surveys to obtain this information. In essence, the survey would collect financial statements. In particular, the flow of funds statement is the most useful. One source of such data comes from financial intermediaries like banks. Such intermediaries invariably require financial statements from borrowers. It should be possible to obtain financial statements of borrowers while respecting privacy concerns. One example of such an exercise is Bachmann and Bayer (2011), who obtained German data on individual firms' financial flows for a limited number of years.

The most limited proposal is that the IRS could be asked to compute and report the external funding measure proposed here by size class in terms of assets, size class in terms of revenues, and by industry. The underlying data is already available and the computations are straightforward. Given the nature of the statistic, confidentiality is not an issue.

The value of this kind of data is that it will allow academics to develop better, more reliable quantitative models of the role of financial markets. 
Such models are essential if we are to ask and answer what the economic consequences would be of policy interventions. For example, one proposal intended to reduce the likelihood of crises is to require banks to hold more capital. If this proposal simply raises borrowing costs for financially constrained firms, it will simply interfere with resource reallocation and will make the economy less efficient.

This kind of data can also be valuable to policymakers. Measuring changes in resource reallocation will allow policymakers to obtain signals about the likely consequences of financial market disturbances on the broader economy.

\subsection{A Critique of Financial Friction Models with a Representative Firm}

Over the last twenty years or so, macroeconomists have developed an array of models in which financial frictions play an essential role. Prominent examples include Bernanke and Gertler (1989), Bernanke, Gertler, Gilchrist (1999), Christiano, Motto, and Rostagno (2009), Jermann and Quadrini (2012), and Gertler and Karadi (2011). The basic idea in these models is that the ability of firms to access capital markets, particularly for investment expenditures, is limited. In Bernanke and Gertler (1989) and Bernanke, Gertler, Gilchrist (1999), for example, investment expenditures (at least at the margin) must be financed by external borrowing. The cost of this external borrowing is higher than the return that firms can receive because of agency problems. In Jermann and Quadrini's formulation, external funds are needed for firms to make profitable investments, and firms face collateral-like constraints on the amount of external funds they can raise. These constraints are thought to arise from the possibility that managers might decamp with some of these funds.

Here I critique this class of models. It should go without saying that the representative firm construct is an exceptionally useful formulation in a wide variety of models. My critique applies only to the role of financial frictions in such models. The main purpose of this critique is to demonstrate the need for disaggregated flow of funds data. Existing aggregate data sources are simply inadequate to analyze how financial market disturbances affect the broader economy.

To develop this critique I present a simple model with financial frictions. Consider the following version of a neoclassical stochastic growth model with financing frictions. I model the financing frictions in the spirit of Kiyotaki and Moore as constraints on the extent to which investment can be financed by borrowing. The time horizon is infinite, the underlying (finite) space of shocks in each period is denoted by $s_{t}$ and the history of shocks is denoted by $s^{t}$ with probability $\mu_{t}\left(s^{t}\right)$ A single consumption-capital good is produced using a neoclassical production function $z_{t} F\left(k_{t}, l_{t}\right)$ where $z_{t}$ is a technology shock, $k_{t}$ denotes capital, and $l_{t}$ denotes labor input. The repre- 
sentative household's utility function is given by $\sum_{t=1}^{\infty} \beta^{t} U\left(c_{t}, l_{t}\right)$ where $c_{t}$ denotes consumption, $U$ is a standard utility function, and $0<\beta<1$ is the discount factor. The resource constraints are given by

$$
c_{t}+x_{t} \leq z_{t} F\left(k_{t}, l_{t}\right) \text {. }
$$

and

$$
k_{t+1}=x_{t}+(1-\delta) k_{t},
$$

where $x_{t}$ denotes gross investment and $\delta$ is the depreciation rate.

The market structure is as follows. Households and firms have access to one period risk-free bonds, which if purchased in period $t$ pay an interest rate $r_{t+1}$ together with the principal in period $t+1$ Firms make investment decisions, employ labor, and distribute dividends denoted by $d_{t}$. The representative household chooses consumption, labor, and bond holdings to solve the following problem:

$$
\max \sum_{t=0}^{\infty} \sum_{s^{t}} \beta^{t} \mu_{t}\left(s^{t}\right) U\left(c_{t}\left(s^{t}\right), l_{t}\left(s^{t}\right)\right)
$$

subject to

$$
c_{t}\left(s^{t}\right)+b_{t+1}\left(s^{t}\right) \leq w_{t}\left(s^{t}\right) l_{t}\left(s^{t}\right)+d_{t}\left(s^{t}\right)+\left(1+r_{t}\left(s^{t-1}\right)\right) b_{t}\left(s^{t-1}\right)
$$

and a no-Ponzi condition $b_{t+1} \geq-\underline{B}$ where $\underline{B}$ is a large number, taking the stochastic process for dividends as given. Let $m_{t}\left(s^{t}\right)=\beta^{t} \mu_{t}\left(s^{t}\right) U_{c}\left(c_{t}\left(s^{t}\right), l_{t}\left(s^{t}\right)\right)$ denote the marginal utility of consumption at $s^{t}$ or alternatively the price of consumption in terms of a numeraire good.

Firms make investment and employment decisions to solve the following problem:

$$
\max \sum_{t=0}^{\infty} \sum_{s^{t}} m_{t}\left(s^{t}\right) d_{t}\left(s^{t}\right)
$$

subject to

$$
\begin{aligned}
d_{t}\left(s^{t}\right)+x_{t}\left(s^{t}\right) \leq & z_{t}\left(s^{t}\right) F\left(k_{t}\left(s^{t-1}\right), l_{t}\left(s^{t}\right)\right)-w_{t}\left(s^{t}\right) l_{t}\left(s^{t}\right)+b_{t+1}\left(s^{t}\right) \\
& -\left(1+r_{t}\left(s^{t-1}\right)\right) b_{t}\left(s^{t-1}\right),
\end{aligned}
$$

equation (1), a nonnengativity constraint on dividends,

$$
d_{t}\left(s^{t}\right) \geq 0,
$$

and an enforcement constraint

$$
k_{t+1}\left(s^{t}\right)-b_{t+1}\left(s^{t}\right) \geq \lambda_{t}\left(s^{t}\right),
$$

where $\lambda_{t}\left(s^{t}\right)$ is a stochastic process that governs the tightness of the enforcement constraint. The idea is that firms are limited in the extent to which they can finance investment by borrowing and that the extent of this limit varies stochastically over time. 
I argue that if the enforcement constraint is binding in any period $t$, the nonnegativity constraint must also be binding in that period. The argument is by arbitrage. Note that consumer optimality implies that

$$
m_{t}\left(s^{t}\right)=\sum_{s^{t+1}} m_{t+1}\left(s^{t+1}\right)\left(1+r_{t+1}\left(s^{t}\right)\right) .
$$

The arbitrage argument is by contradiction. Suppose that the enforcement constraint is binding at some $s^{t}$ and that $d_{t}\left(s^{t}\right)>0$. Reducing $d_{t}\left(s^{t}\right)$ and $b_{t+1}\left(s^{t}\right)$ by a small amount leaves the value of the firm's objective unchanged but relaxes the enforcement constraint and allows for an improvement of the objective. We then have the following proposition:

PROPOSITION 1. Suppose that the enforcement constraint in equation (6) is binding at some $t$ and $s^{t}$. Then $d_{t}\left(s^{t}\right)=0$.

Thus, if a firm pays dividends at some date, then in the model, the enforcement constraint must not be binding in that period. As I will show, in the data for the United States, the aggregate of all firms (and therefore the representative firm in the model) pays dividends almost all the time. From the perspective of the model, the implication is that the enforcement constraint could not have been binding. Fluctuations in the financial frictions parameter, $\lambda_{t}\left(s^{t}\right)$ could not have had any effect.

Consider now alternative ways of modeling financial constraints. These alternative ways are simply different ways of writing the enforcement constraint and they allow for debt to have tax advantages over equity. I argue that financial frictions cannot matter as long as dividends are positive. To make this argument, I will say that financial frictions matter if they distort investment decisions relative to an economy without such constraints. Formally, I say financial frictions matter at $t$ for investment if

$$
\frac{\sum_{s^{t+1}} m_{t+1}\left(s^{t+1}\right)\left[z_{t+1}\left(s^{t+1}\right) F_{k}\left(k_{t+1}\left(s^{t}\right), l_{t+1}\left(s^{t+1}\right)\right)+(1-\delta)\right]}{m_{t}\left(s^{t}\right)}>1 .
$$

The left side of equation (7) is the expected return to capital weighted by the household's marginal rate of substitution and the right side is simply the cost of investing. In an economy without frictions, the two sides of equation (7) are equal to each other. Consider now the problem of maximizing firm profits given by equation (3) subject to equations(4), (1), and (5), and a general formulation of the enforcement constraint of the form

$$
H\left(k_{t}\left(s^{t-1}\right), k_{t+1}\left(s^{t}\right), l_{t}\left(s^{t}\right), b_{t+1}\left(s^{t}\right), b_{t}\left(s^{t-1}\right) ; s^{t}\right) \geq 0,
$$

where the function $H$ is allowed to depend on inherited capital, debt, future capital, and labor. Assume that $H$ is increasing in $k_{t+1}\left(s^{t}\right)$. It is clear that in any solution to this problem, if $d_{t}\left(s^{t}\right)>0$, equation (7) cannot hold. The reason implies that it is feasible to reduce $d_{t}\left(s^{t}\right)$ by a small amount, increase investment in the current period by that amount, and raise dividends in the 
next period by the associated return to capital. We then have the following proposition:

Proposition 2. Assume that $H$ is increasing in $k_{t+1}\left(s^{t}\right)$. Suppose $d_{t}\left(s^{t}\right)>0$. Then financial frictions do not matter at $t$ and state $s^{t}$.

Note that if I also allowed for constant proportional taxes on dividends, proposition 2 still holds.

Figure 15.1 plots dividends for all nonfarm, nonfinancial corporate businesses relative to corporate gross domestic product (GDP) for the United States from 1952:01 to 2011:04. I have taken the data for dividends from table F.102, line 3, and obtained corporate GDP from National Income and Product Accounts (NIPA) table 1.14, line 17. Clearly, dividends are positive for every quarter and typically substantially so compared to gross investment. On average, dividends are 4 percent of corporate GDP. Gross investment (line 11 in table F.102) is 15 percent of corporate GDP on average. In light of propositions 1 and 2, these figures pose a significant challenge for financial friction models that use the representative firm construct.

More generally, it is useful to think of financial markets as consisting of pipes connecting nonfinancial firms to financial intermediaries and households, and to think of financial market disturbances as clogging the flow of funds in these pipes. Many models of financial frictions implicitly think of funds as flowing from households to nonfinancial firms. The problem is that

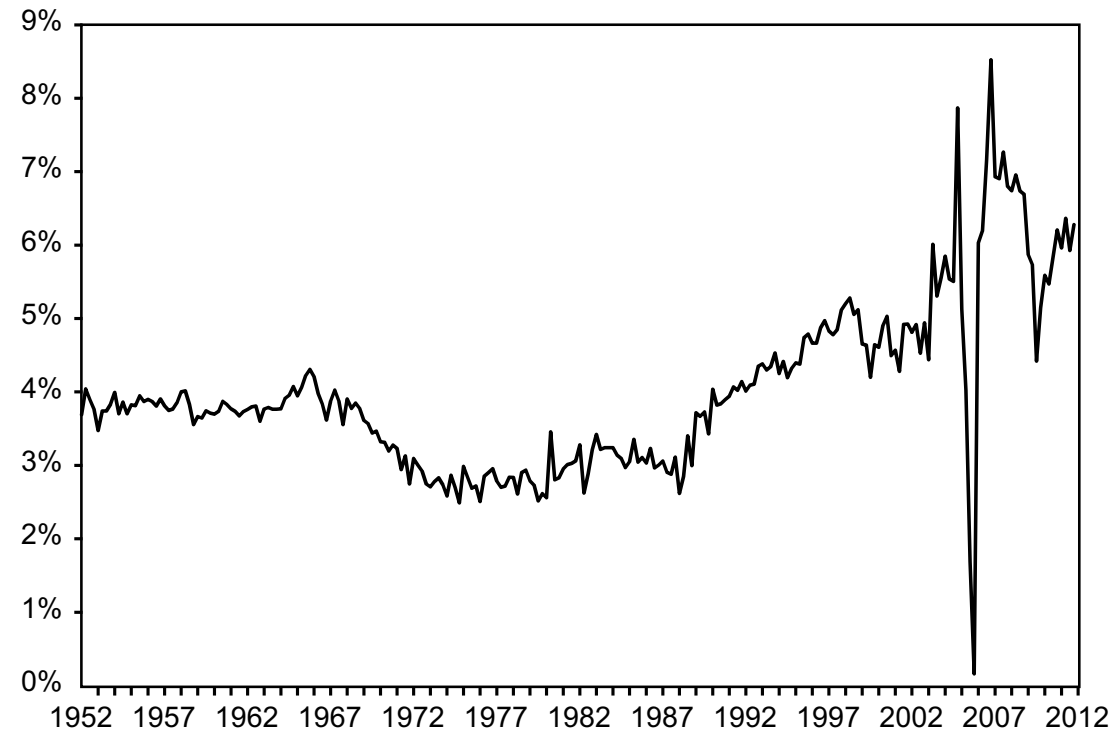

Fig. 15.1 Net dividends, US nonfinancial corporations

Note: See text for description of data. 
in the data, in the aggregate, funds flow from nonfinancial firms to households so that it is hard to see how financial market disturbances interfere with the ability of firms to obtain financing.

To demonstrate the sense in which funds flow from nonfinancial firms to households, it is useful to define a variable that I will call Available Funds. In the context of the previous models, I define available funds as

$$
A F_{t}=y_{t}-w_{t} l_{t}-r_{t} b_{t}-T_{t},
$$

where $y=z_{t} F\left(k_{t}, l_{t}\right)$ denotes output, or value added, and $T_{t}$ denotes taxes. The idea is that interest payments on debt and taxes are legal obligations. Note that I do not include maturing debt. In practice, most debt by nonfinancial firms is long-term debt and only a relatively small amount matures each quarter.

Conceptually, think of firms as obtaining revenues from operations. These revenues net of payments to other firms for materials is simply value added. Subtracting out payments to employees, interest payments on past debts and taxes gives a measure of funds that are available either for gross investment or for financial activities. Such financial activities consist of paying dividends, issuing new debt, retiring old debt, and accumulating financial assets such as claims on households and on financial intermediaries.

Substituting equation (9) into equation (4), we obtain the following accounting identity

$$
d_{t}-\left(b_{t+1}-b_{t}\right)=A F_{t}-x_{t} .
$$

In equation (10), it is useful to note that if $\left(b_{t+1}-b_{t}\right)$ is negative, firms are effectively accumulating net financial assets.

Suppose now that firms follow a policy under which available funds exceed investment at all dates and states. Since it is feasible for firms to pay no dividends, it is feasible for firms to follow a financial policy under which eventually the net financial asset position of firms becomes positive and financing constraints never bind. Eventually, financial frictions cannot matter. Thus a comparison of the behavior of available funds and investment in the data can shed light on the importance of financing constraints.

\subsubsection{Available Funds and Gross Investment in the Data}

I use Flow of Funds data for the United States to construct a comparison between available funds and gross investment. Mechanically, in the Flow of Funds, available funds are computed by adding internal funds (table F.102, line 9) and dividends (table F.102, line 3). Internal funds, in turn, mainly consists of adding retained earnings to depreciation. For gross investment, I use line 11 in table F.102. These data are for all corporations in the United States, including those whose equity is publicly traded and those for which equity is not traded in public markets.

In figure 15.2, I plot available funds and gross investment scaled by gross 


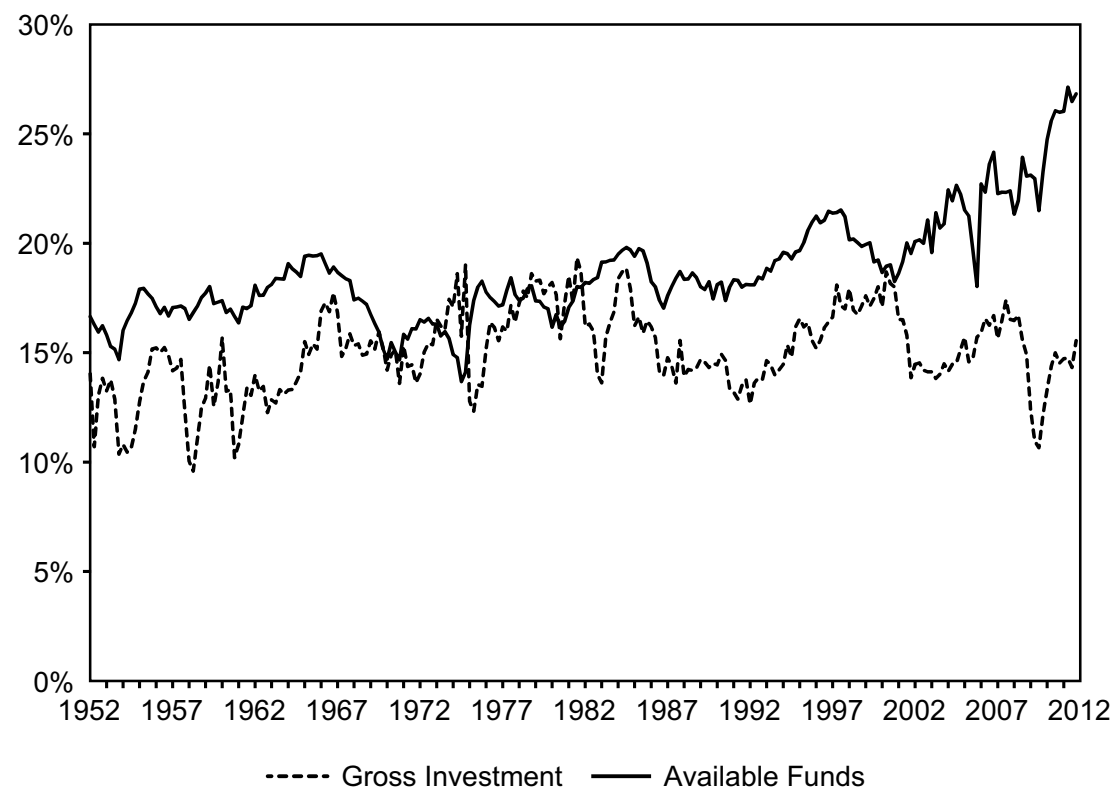

Fig. 15.2 Available funds and gross investment, US nonfinancial corporations Note: See text for description of data.

domestic product for all nonfinancial corporations for the United States for each quarter from 1952:01 to 2011:04. The figure shows that the mean value of available funds relative to nonfinancial corporate GDP is 19 percent, and the mean value of gross investment is 15 percent. On average over the entire period, funds flow from the nonfinancial sector to other sectors. This finding is not surprising since these flows constitute net payments to shareholders of nonfinancial firms and we should expect that the shareholders will be compensated for their investment in these firms. More striking, the figure also shows that available funds exceed gross investment for 217 of the 240 quarters in the data. That is, in over 90 percent of the quarters, available funds exceeds gross investment, and by an economically large amount. Note also that since 1982 available funds has consistently exceeded gross investment, and, in general, by a substantial amount.

I also use the Statistics of Income from the Internal Revenue Service. This data contains summary statistics from tax returns of all corporations and is provided by size class. This data consists of a series of cross-sections. It is the source of much of the information in the Flow of Funds. Using this data, I construct measures of available funds and gross investment for the size classes in the Statistics of Income. This data shows that within each size class, available funds exceed gross investment. In this sense the data does not show any evidence that smaller firms, taken as a whole, are more reliant 
on external finance than larger firms. Figure 15.3 shows available funds and investment normalized by sales for large firms (the largest firms by asset size that account for 70 percent of sales and small firms (the remainder of firms). (The appendix describes the details of the construction.) The figure shows that when firms are aggregated within size classes, available funds consistently exceed gross investment.

Figure 15.4 displays similar statistics for the firms in the COMPUSTAT database where I have scaled available funds and investment by sales. In Compustat, to calculate available funds, I use OANCF when available and its equivalent FOPT for those firms that do not report OANCF at that date. For gross investment, I use CAPX + AQC-SPPE. (Shourideh and Zetlin-Jones [2012] show that the statistics computed from this figure are not driven by outliers.) This figure shows that for public firms, as an aggregate, available funds typically exceed gross investment.

These figures represent a challenge to the literature that uses the representative firm in models in which financial frictions operate through the investment channel. In this literature, financial frictions do end up mattering so next I explore the key ingredients that allow financial frictions to matter.
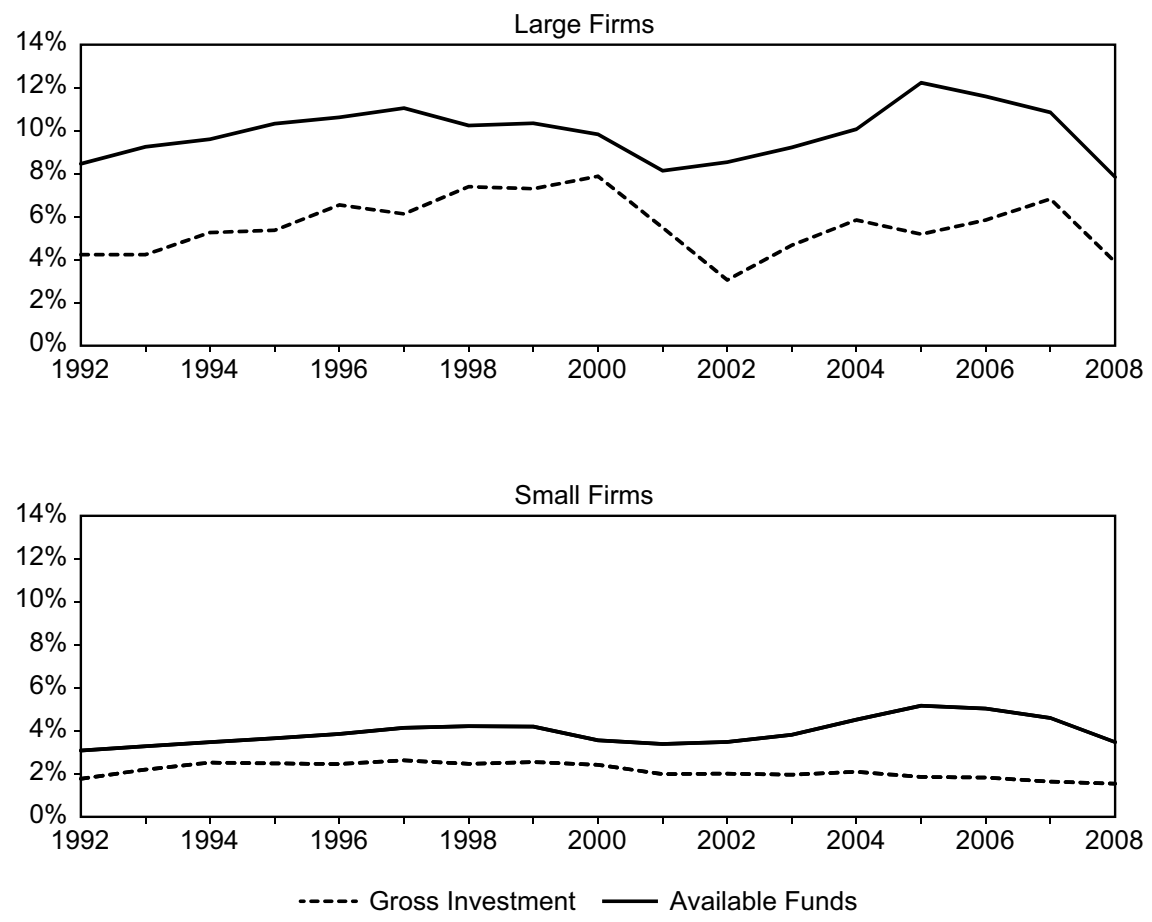

Fig. 15.3 Available funds and gross investment by asset class

Note: See text for description of data. 


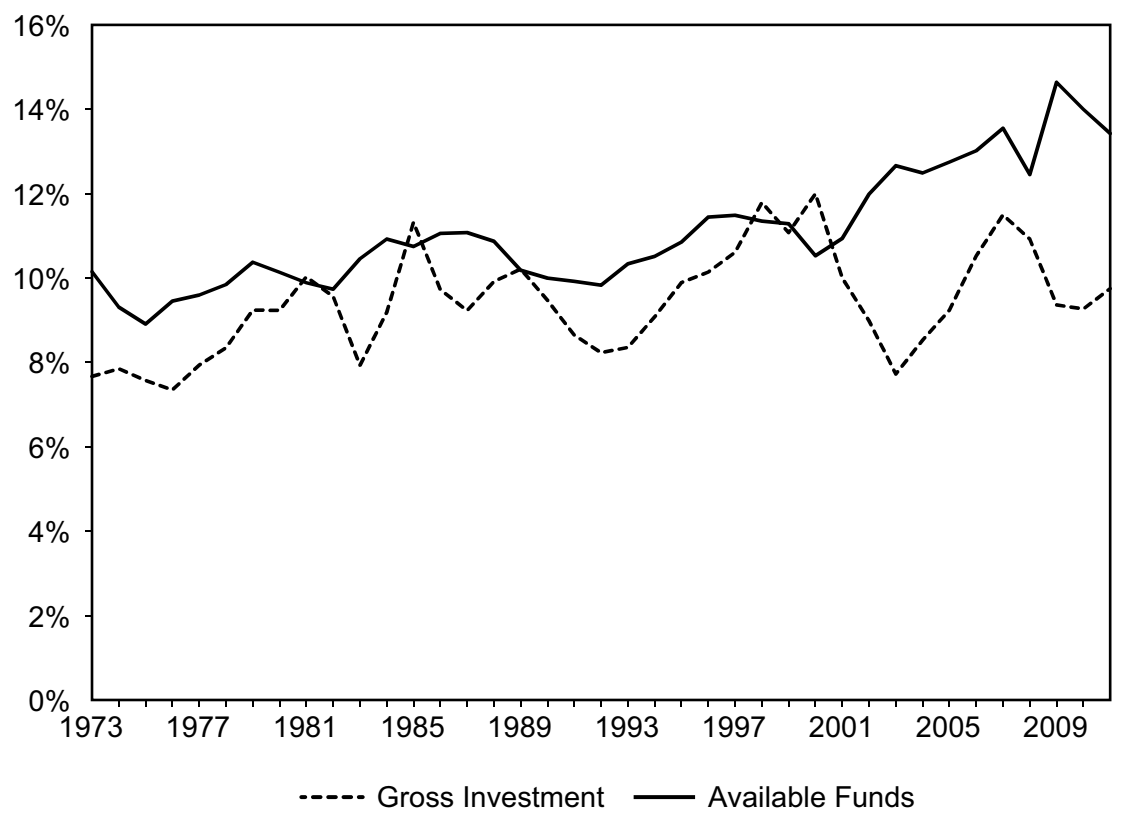

Fig. 15.4 Available funds and gross investment, COMPUSTAT nonfinancial corporations

Note: See text for description of data.

\subsubsection{Adjustment Costs and Other Fixes}

Jermann and Quadrini (2012), in an important paper, develop a model very similar to that previously outlined and argue that financial frictions and collateral shocks play an important role in accounting for the business cycle. The key assumption they make is that it is costly for firms to adjust dividends relative to the steady state level. This assumption implies that financial frictions could matter. The main concern with this fix is that it is not clear how we could measure these adjustment costs using data at the firm level. As a research agenda, it seems preferable to avoid adding ad hoc adjustment costs. Gertler and Karadi (2011), as well as a number of other papers, make similar assumptions about adjustment costs. Such adjustment costs are not easily rationalized as coming from other sources. For example, a large literature in finance (see, for example, Bhattacharya [1979] or Myers and Majluf [1984]) has argued that if managers are better informed than shareholders, dividends could serve as a signal of future cash flows. This literature could be regarded as a rationalization for the reluctance of managers to reduce dividends and their willingness to reduce capital expenditures instead in bad times. One problem with applying the lessons of that literature is that that literature is really about idiosyncratic shocks and not about 
aggregate circumstances. It is difficult to argue that managers have better information about macroeconomic aggregates than shareholders. Financial frictions matter when firms choose to use costly external finance while paying dividends at the same time. In response to an observable macroeconomic shock, any model of optimal contracting between shareholders and managers would allow managers to cut dividends rather than cutting back on profitable investments.

Bernanke, Gertler, and Gilchrist (1999) develop a contracting model in which agency problems induce firms to rely on debt to finance investment. In their model, all dividends are distributed when the entrepreneurs who manage the firm die. One problem with their formulation is that it implies an extremely counterfactual property of dividends at the level of individual firms. They are zero until the firm dies, at which point they spike. Similar concerns apply to Christiano, Motto, and Rostagno (2009).

It is worth emphasizing that this literature has been extremely valuable. It is quantitative and it deals with general equilibrium effects and tries to grapple with the effect of financial frictions on output, employment, investment, and so on. In that sense, it represents a considerable advance over illustrative two or three period models that are common in the literature on financial intermediation.

The concerns I have raised about the representative firm construct in models of financial frictions operating through the investment channel do not imply, of course, that all models of financial frictions are doomed. Models focusing on reallocation of investment funds offer a promising alternative.

\subsection{Macroeconomic Models with Reallocation and Disaggregated Data}

Models that focus on the role of financial frictions in inhibiting the reallocation of funds across firms seem promising. In Kiyotaki and Moore (1997), Eisfeldt and Rampini (2006), Buera (2009), or Shourideh and Zetlin-Jones (2012), the key role of financial markets is that they allow funds to be reallocated from cash-rich, project-poor firms to cash-poor, project-rich firms. Disturbances in financial markets can then be thought of as affecting the reallocation of funds and therefore the efficiency with which the economy operates.

In this context, I propose a statistic that I will call the external funding measure. This measure is computed using the concepts of available finds and gross investment defined earlier. Specifically, suppose we have data on available funds and gross investment for a sample of firms. Let $x_{i t}$ and $A F_{i t}$ denote gross investment and available funds for firm $i$ in period $t$. Then the external funding measure in period $t$ is given by

$$
E F_{t}=\frac{\sum_{i}\left(x_{i t}-A F_{i t} * x_{i t}>A F_{i t}\right)}{\sum_{i} x_{i t}},
$$


and the average over the sample period is given by

$$
E F=\frac{1}{T} \sum_{t=1}^{t=T} E F_{t} .
$$

This statistic is a measure of the extent to which firms rely on external funds to finance investment. To obtain it, I add up all investment in excess of available funds and scale it by aggregate investment. This statistic is a natural measure of the reliance of firms in making investments on financial markets. This natural measure is useful for two reasons. Measuring the extent to which it fluctuates over time and determining its correlation with other measures of stress in financial markets provides real-time information on the extent to which real variables like investment are affected by financial market disturbances. Second, obtaining data on the business cycle properties of this statistic can discipline the building of quantitative general equilibrium models. Shourideh and Zetlin-Jones (2012) show that this measure plays a central role in calibrating their quantitative general equilibrium model.

Like all statistics of the data, this one should be treated with caution. For example, in a world where financial markets do not function at all, no firm is able to obtain external financing and the value of the statistic is zero. This observation suggests that the value of this statistic is to provide clues, rather than definitive answers, in real time and to discipline the construction of quantitative models.

Computing the external finance measure requires disaggregated data at the level of individual firms. For the United States, data on the balance sheets and income statements are not publicly available for all firms. Such data is available for firms whose shares are traded in public markets. Compustat offers a convenient source for these statements. Using data from Compustat, it is possible to calculate available funds and gross investment (as described earlier) for publicly traded firms. Figure 15.5 shows the time series for the external funding measure. The sample average is 23 percent. Note also that this measure varies considerably over time and seems to be procyclical. While this finding is promising, Shourideh and Zetlin-Jones (2012) show that when a model is calibrated to data from Compustat, the effects of financial frictions are fairly modest.

Shourideh and Zetlin-Jones (2012) obtain data from a data set called Amadeus. This data set contains financial information for a much larger set of firms for a number of European countries. This data contains financial information for both publicly traded companies and for privately held ones. Using this data, they show that for the United Kingdom, the sample average of the external finance measure for the period from 2000 to 2009 is 90 percent. The observation that privately held firms are so much more reliant on external finance is promising for models that emphasize the role of financial markets in reallocating investment funds from cash-rich, project-poor firms to cash-poor, project-rich ones.

A key lesson from the Shourideh and Zetlin-Jones exercise is that publicly 


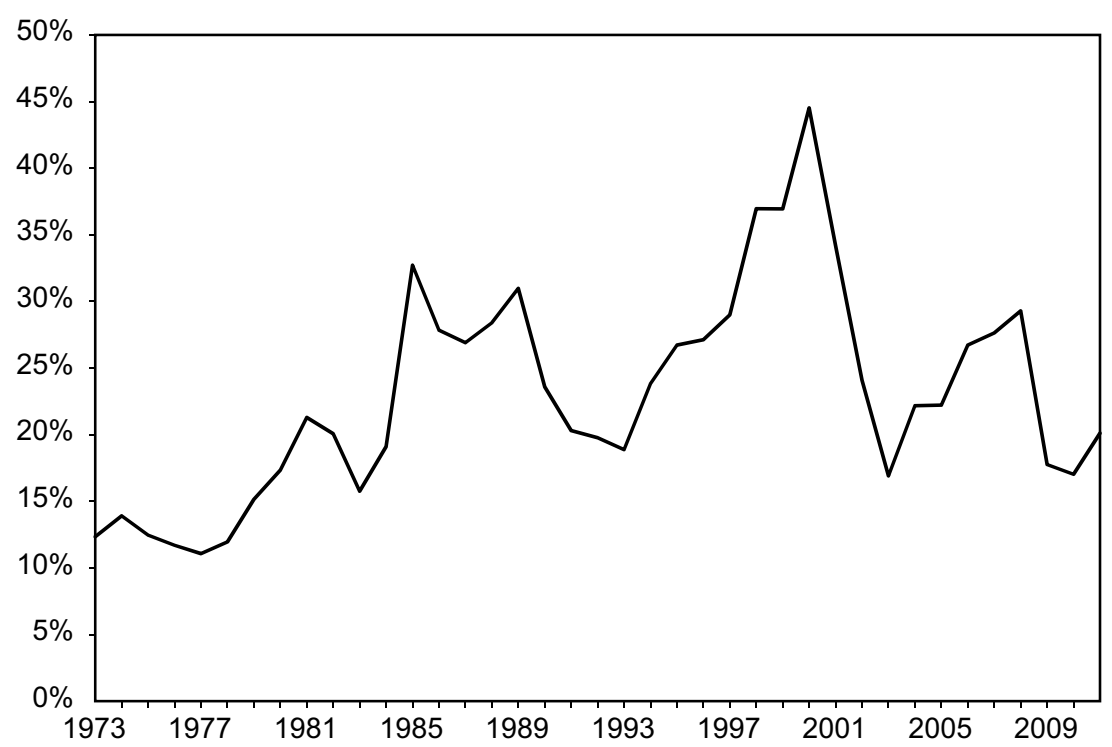

Fig. 15.5 External funding measure, COMPUSTAT nonfinancial corporations Note: See text for description of data.

held and privately held firms are very different in terms of their reliance on financial markets for financing investments. This lesson suggests that policymakers and academics would benefit greatly from access to financial statements of privately held firms in the United States.

\subsubsection{A Proposal for Disaggregated Data}

I have argued that representative firm models are not useful for studying the role of financial frictions operating through the investment channel and that heterogeneous firm models are much more promising in this regard. In order to discipline the development of heterogeneous firm models, however, we need disaggregated data on financial statements of individual firms. Such data is available for publicly held firms. In terms of privately held firms, financial statements are available for the last decade or so for a number of European countries and the Amadeus data set offers a convenient way of accessing the data. For the United States, it would be exceptionally useful if financial statements were available for privately held firms. Here, I outline three options starting with the ideal outcome and proceeding toward acceptable outcomes for obtaining similar data for the United States.

The Internal Revenue Service already has this data since corporations are required to report extensive information on their finances along with their tax returns. The ideal outcome would be for the IRS to make available the underlying balance sheet information for privately held firms. Obviously, 
academics and policymakers do not necessarily need data for the entire population. A suitably chosen random sample should suffice. It is worth emphasizing that this random sample should be in the form of a panel rather than a repeated cross-section. One reason is that many firms may choose to access financial markets in times when their individual fortunes are relatively good in order to have funds available when investment needs are particularly high.

If the IRS is unwilling to make this data public, the Federal Reserve or other organizations could conduct surveys to obtain this information. In essence, the survey would collect financial statements. One possible source of such financial statements is banks. Borrowers are invariably required to provide financial statements to banks. As with all corporations, such statements consist of a balance sheet, an income statement, and a flow of funds statement. Of these, the flow of funds statement is the most useful.

If such surveys cannot be conducted, for example, because of concerns of low response rates, the IRS could be asked to compute and report the external funding measure proposed earlier by size class in terms of assets, size class in terms of revenues, and by industry. The underlying data is already available and the computations are straightforward. Given the nature of the statistic, confidentiality is not an issue.

\section{Appendix}

\section{Appendix for the Statistics of Income Analysis}

This appendix describes the computation underlying figure 15.4. All data are taken from Annual Statistics of Income, Corporation Income Tax Returns, Table 2: Balance Sheet, Income Statement, and Selected other items, by size of total assets (Returns of Active Corporations), 1992 to 2008.

\section{Data Definitions}

- Available funds = total receipts less total deductions plus deductions for depreciation (including depreciation, amortization, and depletion).

- Fixed assets $=$ depreciable assets less accumulated depreciation plus depletable assets less accumulated depletion plus intangible assets less accumulated amortization plus land.

- Sales = total receipts.

- Depreciation $=$ change in accumulated depreciation plus accumulated depletion plus accumulated amortization.

- Investment $=$ fixed assets plus other assets plus depreciation.

Note that deductions for depreciation is not equal to accumulated depreciation. 


\section{Computing Statistics for Small and Large Firms}

The statistics of income reports data for all firms within a given bin for nominal assets. Let the upper bound of the bins on nominal assets be denoted

$$
\left(x_{0}, x_{1}, x_{2}, x_{3}, x_{4}, x_{5}, x_{6}, x_{7}\right)=(.5,1,5,10,25,50,100,250),
$$

representing \$500,000, \$1 million, \$5 million, \$10 million, \$25 million, $\$ 50$ million, $\$ 100$ million, and \$250 million.

\section{Step 1: Aggregate to consistent bins.}

Nominal bins changes in 2001. We aggregate the highest values after 2001 (values between $\$ 250$ million and $\infty$ ) and we aggregate up to $\$ 500,000$ before 2001.

Let $Y_{t}^{\text {raw }}\left(x_{i}\right)$ denote the raw series level in year $t$ for all firms with assets between $x_{i-1}$ and $x_{i}$.

Let $\bar{Y}_{t}$ denote the raw series level in year $t$ for all firms.

Step 2: Convert to (level of) real data.

Let $y_{t}\left(x_{i}\right)$ denote the raw data after it has been made real using the implicit GNP deflator (my current base year is 2005).

Step 3: Compute empirical cumulative distribution.

Let

$$
S\left(x_{i}, t\right)=\sum_{j=0}^{i} y_{t}\left(x_{j}\right) .
$$

Note that $S\left(x_{7}, t\right) \neq \bar{Y}_{t}$, since I have not included a "highest" bin value.

Step 4: Construct a continuous function $S(x, t)$.

We use the spline.m function provided by matlab applied to the log of $S\left(x_{i}, t\right)$ and the $\log$ of $x_{i}$. (Specifically, let $\bar{x}$ be the vector of $\log \left(x_{i}\right)$ and $\bar{S}$ the vector of $\log \left(S\left(x_{i}, t\right)\right)$. Then for any value, $x$,

$$
S(x, t)=\exp (\operatorname{spline}(\bar{x}, \bar{S}, \log (x)) .
$$

Step 5: Defining cutoffs.

We use sales to define the small and large asset cutoffs. Suppose we assume that small firms make up $30 \%$ of sales in any year. Then, in each year, $t$, let $c(t)$ be the value such that

$$
S^{\text {sales }}(c(t), t)=.3 \bar{Y}_{t}^{\text {sales }} .
$$

Available funds for small firms is then given by

$$
A F_{t}^{S}=S^{\text {in.funds }}(c(t), t)+S^{\text {dep }}(c(t), t),
$$

and for large firms 


$$
A F_{t}^{L}=\bar{Y}_{t}^{\text {in. funds }}-S^{\text {in. funds }}(c(t), t)+\bar{Y}_{t}^{\text {dep }}-S^{\text {dep }}(c(t), t) .
$$

To compute capital expenditures, we need the change in fixed assets. For this, we need to correct for growth in total assets and inflation to ensure firms stay approximately within the same bin. In particular, in any year $t$, let

$$
z_{t, t-1}=c(t)\left(1-g_{t-1, t}+\pi_{t-1, t}\right) .
$$

Then, capital expenditures for small firms is given by

$$
\text { Cap } X_{t}^{S}=S^{f i x a}(c(t), t)+S^{d e p}(c(t), t)-S^{f i x a}\left(z_{t, t-1}, t-1\right),
$$

and for large firms

$$
\operatorname{Cap} X_{t}^{L}=\bar{Y}_{t}^{\text {fixa }}+\bar{Y}_{t}^{\text {dep }}-\bar{Y}_{t}^{f i x a}-\operatorname{Cap} X_{t}^{S} .
$$

\section{References}

Bachmann, R., and C. Bayer. 2011. "Uncertainty Business Cycles—Really?” NBER Working Paper no. 16862, Cambridge, MA.

Bernanke, B., and M. Gertler. 1989. "Agency Costs, Net Worth, and Business Fluctuations." American Economic Review 79:14-31.

Bernanke, B., M. Gertler, and S. Gilchrist. 1999. "The Financial Accelerator in a Quantitative Business Cycle Framework." In Handbook of Macroeconomics, edited by John B. Taylor and Michael Woodford, 1341-1393. Amsterdam: Elsevier Science, North-Holland.

Bhattacharya, S. 1979. "Imperfect Information, Dividend Policy, and the 'Bird in the Hand' Fallacy." Bell Journal of Economics and Management Science 10:259-70.

Buera, F. 2009. "A Dynamic Model of Entrepreneurship with Borrowing Constraints." Annals of Finance 5 (3-4): 443-64.

Christiano, L., R. Motto, and M. Rostagno. 2009. "Financial Factors in Economic Fluctuations." Working Paper, Northwestern University.

Eisfeldt, A. L., and A. Rampini. 2006. "Capital Reallocation and Liquidity.” Journal of Monetary Economics 53:369-99. .2009. "Financing Shortfalls and the Value of Aggregate Liquidity." Working Paper, Duke University.

Gertler, M., and P. Karadi. 2011. "A Model of Unconventional Monetary Policy." Journal of Monetary Economics 58 (1): 17-34.

Jermann, U., and V. Quadrini. 2012. "Macroeconomic Effects of Financial Shocks." American Economic Review 102 (1): 238-71.

Kiyotaki, N., and J. Moore. 1997. "Credit Cycles." Journal of Political Economy 105:211-48.

Myers S. C., and N. Majluf. 1984. "Corporate Financing Decisions When Firms Have Information That Investors Do Not Have." Journal of Financial Economics 13:187-220.

Reinhart, C., and K. Rogoff. 2009. This Time is Different: Eight Centuries of Financial Folly. Princeton, NJ: Princeton University Press.

Shourideh, A., and A. Zetlin-Jones. 2012. "External Financing and the Role of Financial Frictions over the Business Cycle: Measurement and Theory." Working Paper, University of Minnesota. 